\title{
DE GEBOORTE VAN ONS CONGULAAT TE CANTON UIT HET VERLEDEN VAN NEDERLANDS HANDEL OP CHINA.
}

Reeds kort na Nederlands Herstel, nl. in 1815, werd een monopoliseerende Theemaatschappij gewetigd. Een der meest warme ondersteuners ervan was de departementschef voor de Koloniër Goldlierg; echter geen minister, doch directeur-generaal. In die positie heeft hij over de uitzendling ran een voor rekening der Maatschappij gehuurd raartuig en wat verder tot de zaak betrekking had, een breede correspondentie moeten voeren, o.a. met de onder die Oost-Indische Compagnie werkzaram geweest zijnde leden der factorij te Canton. Deze heeren zijn later benoemcl biji het in het leven te roepen $\mathrm{Ne}$ derlanidsch consulaat aldiaar; maar zij bleven hcpfuien van de officieele handelsinsteling, die men alzoo handhaafdre, echter met een belangrijk ander karakter. Brieven enz. over een en ardler liogen op het Algemeen Rijksarchief te 's-Gravenhage in $\mathrm{K}$ ol o $\mathrm{n}$ i ë $\mathrm{n} \mathrm{n}$ a 1813, bundels 216 $\mathrm{t} / \mathrm{m} 218$, met 219 als agenda; ook zal ik nog geleizenheid hebben de aandacht te vestigen op een daar buiten gelegen resolutie betrekkelijk het Canton-consulaat. Nadat ik van deze stukken vroejer kennis genomen had-burdel 216 is echter van geen belang - opende ik ze opnieuw ondier den indruk der leziner ram drie in belangrijkhieid wedijverende publicatiën, die, ondanks verschillend karakter, cp elkander tetrekking hebber en nochtans onafhiankelijk ran elkander, toevallig genoeg, in $1917-1918$ als tegelijkertidd rerschenen. Het kwam mij voor, dat in rermelde bundels stof voor lezenswaardige aanvulling lag. Ik vang aan met het noemen eensdeels van de bedioelde publicatiën, andersdeels vam evenzeer meerdiere malen aan te halen schrifturen; dan vorderen de verwizingen geen, vreede noten.

1. De reide deeler van $D$ e $G$ i d s van 1917 bevatten hoofdstukken van een aantrekkelijke verhandelingh, verdeeld over verschililende tidvalken, geschreven door Dr. $\mathrm{H}$ endrik P. N. M ull e r over ,Onze vaderen in China", di. 1: I. 1584-1624 op bl. 321 ; II. 
1624-1668 op bl. 328 ; III. 1668-1734 op bl. 504; di. 2 : IV. $1734-1824$ op b]. 163 ; V. $1824-1863$ op bl. 327; VI. 1863 tot hedien op bl. 361. Dit artikel wordt ten aanzien van een klein, doch gewichitig tijkllvak op hoogst verdienstelijke wijze aangevuld.

2. In de Bijdragen van hiet Kon. Instituut voor Taal-, Land- en Volkenkiunde te 's-Gravenhage door Dr. J. d.e Hullu in dl. 73 (bl. 32-151), verscheen nl. een: evenzeer breed aangelegde verhandeling: ,Orer den Chinaschen handel der Oost-Indische Compagnie in de eerste dertig jaren van de 18 eeuw". Men zou wat meer opgewaktheid, ook wat meer eenheid in de voorstelling wenschen"; zoo'n inwerpen vain de Compagrie van Ostende (bl. 40-63) is ook geen kleinigheid om, gelijk het ietwat saai gegeven werd, te verciuwen. De waardeering van deze verhandeling door Dr. Muller in dl. 1 , bl. 519 , noot 1, der "Vadieren", is niettemin geheel op haar plaats. En hetgeen men cloor cle beperking van die E erste dertig jaren van Dr. Hullu mist, vindt de lezer door Muller zelf geheel vergoed.

3. Het ,M e m o $\mathrm{r}$ i e b o e $\mathrm{k}$ van pakhuismeesteren van de Thee te Amsterdam 1818-1918 en de Nederlandische theehandiel in den loop der tijuen." Toen, gedirende dien loop ran 1917, Muller en De Hullư zich in China verdiept bleken te hebben, sloten, na van de vruchten hunner studiën gebruik te maken, ,Pakhuismeesteren van de Thee Bierens de Haan", door wier tusschienkomst nog altijd te Amsterdam de theeveilingen worden gehoudien, het gewichtige Memorieloek d.d. 31 December van dat jaar af, gelijk wij lezen op bl. VIII der Inleidling vani het fraai uitgegeven werk.

4. De op bl. 827 vermeld'e Theemaatschappij van 1815 heeft een droevig en kort bestaan gehad; reeds op het einde van 1817 deed de wet haar sneven. Wij hebiben dararaan te danken een gedirtule To elichting van de regeering d.d 22 October 1817 en een gedrukt $\mathrm{R}$ a $\mathrm{p}$ p o $\mathrm{t} t$ van de Centrale ardeeling d.d. 10 December d. a.v., voorhandlen o.a. in de kibliotheek van bovenvermeld Kon. Instittout: zie den catalogus ran 1908, b1. $423, n^{\circ} .192$.

5e. Terwill deze aangelegenheid: nog hangende was, presenteerde zich aan het publiek iemand, die zijn $\mathrm{Va}$ derland ,hartelijk beminnende" zeide, in een slecht geschreven brochure, getiteld ,Onderzoek of het belang van den Nederlandschen handel raadlzaam zij den invoer van thee in dat koningriik al dan niet vrij te stellen" (1817). De schrijver droeg den weinig gelukkigen naam van P. Pous. Het boekje wordt meide door den ver- 
melden catalogus uitgetrokken op dezelfde bladbrijde onder $\mathrm{N}^{\circ} .189$.

Men vergeet het weleens, malar de alles onder zijn hoede nemende Oost-Inclische Compagnie, had den theehandel buiten het monopolie gesteld. De gevolgen waren prachtig geweest. In weerwil hiervan kwamen statenGeneraal op het einde der 18 eeuw, toen men rog niet dood of failliet was, doch reeds te zwak feitelijik om een veer van den mond te blazen, met de vraag bij de Comparnie of men dien handel óók niet zou monopoliseeren. Wat graag! was het antwoord, gedagteekend Amstendlam, 2 Octoler 17\%10. Hєt wees er wel op, chat wanneer men de menschen aldus den diuivel in het hart joeg, hieruit slechte gevolgen konden voortvloeien, terwijl indien de handiel noodgedwongen eenmaal was verplaatst, men dat niet gemalkkelijk kon herstellen, en allzoc een proef kwalijk viel te overwegen; doch, daar zij betoogden, waarom die gevolgen niet te vreezen zouden zijn, lieten Staten-Generaal zich yan het door hen geopperd dienkbeeld ook niet afbrengen, ertoe besluitende bij resolutie van 15 Fe'bruari 1791. In de hiervoren ondier $4^{c}$ en $5^{*}$ vermelde gedrukten van $T h$ e e wet en P o us wordit over die proef gesproken; ik zal daarop echter hlier niet terugkomen. Advies en Resolutie zijn. in één band voorhanden, blijkens den vermelden catalogus, bl. 146, No. 160.

I.

,Met geen ander land in het Oosten heeft de Compagnie zoo laat vaste, onafgebroken handelsbetrekikingen aangeknoopt als met Chlina", is opgemerkt geworden. ${ }^{1)}$ Een cler oorzaken hiervan was gelegen in de betrekkelijk drukke vaart der Chineesche schlepen, jonken, op plaatsen van onzen Archipel, w.o. op Batavia; aanbrengende wat die XVIIen in Holland vooral van daar verlangden: thee. Voor de Compagnie werd deze tusschenhandiel voordeeligier geacht, dan dat zijzelve, dlus op eigen risico, het product uit China haaldie. Eerst in dien aanvang der $1 \varepsilon^{\circ}$ eeuw kwam men in Holland ten deze tot andere gedachten; doch daar de regeering te Batavia den tusschenhandel bleef verkiezen - ook wegens de vele geldelijke voordeelen, die de jonkenvaart aan de openbare kas aldaar opleverde - en uit dien hoofde zich van medewerking tot de door die Bewindhebbers gewenschte vaart onthield, Lesloten de

1) De Hullu t. a. p., bl. 32 . 
XVIIen de zaak zelven ter hand te nemen. 1) Vapudtaar hun bericht in 1728 aan Batavia, dat tot rechitstreeksche zending uit Holland ran schepen naar China was besloten, oncier verwijt aan de Indische regeering: dat zij , maar steeds geen schepen naar China bad willen zenden om daar zelf de beroodigcie waren te gaan afhar len". ") De chaad bij het woord roegencie, ging de Coxhorn, om te hegininen, er op uit. Den $2^{\mathrm{n}}$ Augustus 1729 bereilite het schip Macao, na een reis van bijna \& maanden; den volgenden cilag roer men met een Chineesch vaartuig de rivier van Canton op, ongeveer 3 uur, ter bereiking van deze plaats. ${ }^{3}$ ) Den $1^{\mathrm{cn}}$ Januari 1730 werd naar het raderland teruggezeild, waar men den $13^{\mathrm{en}}$ Juli dia.r. aaniwam, recht terrecen over de fraaie en zeer winstgerende lading. Hot laatste der zes expeditiën, die met 12 schepen in het geheel dergelijke reizen hebben ondiernomen, was ie NoordWolfsbergen van $1734 \mathrm{cp} 1725$. Toen liwam ar weder kentering in deze vaart. Er werden wel vele voordeelen met den handel op zichze'f verkregen; maar de zware kosten maakten de expeciitiën te minder loonend, omklat de eerste vertrouwensmannen of de schepen, en in nanolging de ondergeschikten, zich aan hun plichten niet hiclden en alzoo groote schacie veroorzaalten. Trouwens de Indische regeering liet zich eindelijk yezeggen om roor scheper naar China te zorgen, terwiil zij in haar, bekommering." roor die jonker.valart (recdis in $17: 23$ vanzelf opnieuw aangerangen) een mididenwos uitrond, dkor enkel met onze schepen thee en dergelijke roor Iolland gewenschte waren lit China te chen hatlen, derhalie geene voor de Indische markt bestemde artikelen, die alzon ten behoeve van den overvoer door jonken keschiktaar Weren. ${ }^{4}$ )

Het is ten gevolge ran deze zeer laat ingetreden meer regelmatige raart onzer schepen naar China, dat wit niet

1) Zie in het breede bij De Hullu, t. a. p. bl. 63 v.v.

2) De Hullu t. a. p. bl. 62.

3) Op deze vaart heeft betrekking, wat vermeld staat in Muller t.a.p. dl. I, bl. 516-517.

4) Over het hier medegedeelde $D_{e}$ Hullu t. a. p. bl. 69 v. v. Op het streven om de jonkenvaart onder het bestuur van landvoogd Van Imhoff in het midden der $18^{\circ}$ eeuw en vroeger te beschermen, kom ik terug in mijn ter perse liggend Nijhoffwerk. Men liet daartoe de schepen geen invoerrechten betalen naar de goederen, die zij aanbrachten, doch een vaste voor alle gevallen bepaalde som; deze zonderlinge regeling bleef, met onderisreking tijdens het Engelsch tusschenbestuur, bestaan tot ver in de $19^{\mathrm{e}}$ eeuw! Zie intusschen Mr. N. P. van den Berg's *Historisch-Statistische Bijdragen» (1907), bl. 289-289, 305. 


\section{1}

vroeger vernemen van een Nederlandschie factorij te Canton, waaruit, naar wij aan het slot dezer verhandieling zullen lezen, zich ons consulaat ontpopt heeft. Eerst de instructie, aan de vermelde Coxhorn medegegeven, handlelde over die "factorij of loge, als er te Canton een mocht worden opgericht". ${ }^{1}$ ) Van een oprichting lezen wij cchter niets nader, totdat we onverwacht melding zien gemaakt van "de factorij". Onze handel had er toch een huis noodig om het personeel en de goederen te kunnen bergen, terwijl men verplicht was wel een klein half jaar te Canton te verblijven. De rezoekers vergenoegden zich slestidds enkel met cen van cen Chinees ingehuurd gebouw, waarvan men de huishouding weer geheel opbrak, toen de Coxhorn Canton verliet. Onder den hanclel van de daarop volgende schepen is het evenzoo gegaan. Toen echter de hedenlingen, die tegen onze vaart naar China door de Indische regeering waren in het mididen gebracht, de XVIIen opnieuw in 1734-1735 dieden schrijren om de ondernemingen van Batavia te doen plaats hebren, witten zij de wenschelijkheid, dat in China zoude worden gewettigd: ,een permanent comptoir", wedcrom met de bi:roeging: indien die overheid het veroorloofde, hetgeen nog zoo zeker niet scheen. ") Ook bevalen de bewindhebhers aar om met de naar China te zenden schepen medx te geven: "drie à vier personen tot het bestier van Compagnieshandel aldaar en dat wel met zoodanigen rang", als men geraden mocht vinden. De Indische regeering droeg dientengevolge aan hen, die de vart naar Canton ondernamen, nog in 1742 instantel $\mathrm{k}$ op om voor de vestiging eener factorij hun, ,uyterste best te doen". Eindelijk gielukte het in 1749 ; hoe de factorij te Canton materieel werd ingericht, is ons op belangwekkende wijze mederedeeld; van de personeele organisatie vernemen wij echter niets. ${ }^{3}$ ) Het is eigenaardig, dat wij in latere tijden ook hiervan geen bericht hebben; zelfs na het Herstel weten we eigenlijk niet, waarop en hoedanig halar organisatie zichi eigenlijk grondde, totdat ze in een consulaat werd opgelost.

Het leven dezer stichiting van de tweede helft der 18 e eeuw scheen slechts kort te zullen duren. Als men een vaste vestiging had, behoorde men ook menschen ervoor te benoemen, dus werd het een kostbare geschiedenis, waarvan de Compagnie bij den achteruitgang der zaken

1) De Hullue t. a. p., bl. 73.

') De Hullu t. a. p., bl. 126, 128, 135.

3) De Hullu t. a. p., bl. 89-95.

Econ. 1918. 
spoedig genocg had. Reeds in 1756 ontving de Indische regeering, aan wie sinds 1735 de China-handiel weder geheel was toerertrouwd, het berel, dat, ide huishou. ding te Canton moet worden opgehroken". ") Deed echter ook hier het Oost-Indischudcof zi n rechten gelden? Want in 1773 en 1787 rind ik incidlentecl nog altijd ran die factorlif cloor officicele stulien gewarg gemaatit en over de gebeurtenissen ran 1791 geworit ons de verzckering: , $\Delta l$ ciien tid leefice de factorij voort." ")

\section{II.}

De revolutie van het einde der 18 ecuw met haar treurige gevolgen roor stant, kolonien, handel biet de factorij der Compagnie te Canton, althans roor het uitwendige, onteroercl, zolfs de oplossing van Holland in het Fransche keizerrijk vernictigde haar als Nederlandsche instelling geenszins finaal. "i) J. H. Bletterman, een heelmeester, in den handel orerycgatan, misschic!n wel tegelijk geneesheer gebleren en hierdoor snede bij de Chineesche gemeente in a anzion, was er, bijgestan door Bernardus Zeeman, tijdens die voor hem en zijn confrater mociclijke dagen als conservator. ,Tot een bewijs in welke achting de Hollandsche Naam bij de Chinezen staat, dient", mcmoreerde iemand. in 1817 ): , , lat niet alleen de Engelschen in aile humne oorlogen met ons, nimmer hebben kunnen slagen, om de vlag van de Hollandsche Factoric, te Canton te doen afremen, maar zells in den tijd, dat ons Vaderland met Frankridi was ingeliffl, en de Hollanders dus ophielden als Natie te hestaan, de Hollandsche Factorie op Canton niet alleen die naam herft behouden, maar men zelfs zegt: dat de Hollandsche Vlag, claarvan, op rerzoek der Chinezen, is blijven waaijen..." 5) Die landsdienaren bleven trouw hun plichten vervullen, gelijk ook op Decima het geval zou bljken te zin, coch genen zonder de moeilijkheden en de verleidingen, waaraan dezen van de zijc.e der Engelschen blootgesteld zoudien worden. ${ }^{6}$ ) Te Canton waren door ons gocderen ingeslagen, die betaald moesten wordien, doch warroor geen schepen

1) Muller t. a. p., dl. II, bl. 164 .

2) Verg. Muller t. a. p., dl. II, bl. 166.

3) Verg. Muller t. a. p. dl. II, bl. 171-172.

1) Pous t. a. p., bl. 24, noot.

5) Zie ook een getuigenis over de «Ho-lan» bij Muller t. a.p. dl. II, bl. 332.

6) Zie mijn Decima-artikelen in het Koloniaal Tijdschrift van November 1918 (bl. 1347-1369) en in Nederlandsch-Indië Ond en Nienu van December 1918, bl. 246-248. 
kwamen en dus ook geen fondsen, zoowel roor die voldoening daarvan als voor dle betaling der inkomsten van het personeel. Daartoe redde men zich met geldopneming tegen 12 i $15 \%$ : , zoodat op 30 November 1814 de schuld der factorij hijna f 377.000 beliep" ${ }^{1}$ ), wèl een sprekendie getuigenis voor het groote crediet, dat die Nederlardsche naam er genoot; evenzoo weder als op Decima.

De tijding van Nederlands Herstel in 1813 decd overal, waar de oudgedienden der Compagnic leeflen, en zoo ook onze voormalige ambtenaren der Chineesche factorij en die tot haar in betrekking hadden gestaan, met. vreugde vervullen. ") Gaarne $z \mathrm{ij}$ aangenomen, dat de ethische geroelens van cle vadierlandsliefde en van het nu weer zichzelf zijn, daartij van gewicht waren; doch tevens zal er de gedachte toe medegewerkt heblen, dat men geldelijke positiën zou rerbeterd zien en voorgeschoten gelden terugerlangen. Volgens het archief ${ }_{7}$ Goldberg bestond het personeel der factorij eincle 1813 uit één eersten supercarga, twee assistenten en één oppermeester. ${ }^{3}$ ) Hoe dat eigenlijik is, weet ik nict, stellige gegevens missendie. Behalve de vermeide Bletterman en Zeeman, vind ik slechts als gewezen ambtenaar genoemd Rabihel. De firma Theysset en $\mathrm{C}^{0}$. te $\Lambda$ msterdam was hun gemachtigde; in haar corresponclentie met der departementschef Goldberg, noemt zij hen hare ,vrienden", ,alle bedienden van de Nederlarysche factorij te Canton". Napoleon's terugkomst van Elba verstoordie een oogenblik de vreugdle zoowel in China als op Java over de gebeurtenissen van 1813. Orze consul May te Londlen berichtte d.d. 29 December 1815 hierover aan Goldberg: ,,Den 28 July hebben ze op Batavia ontfangen de couranten van hier van 1 April - de verslagendiseid was onder onze Landsgenoten zeer groot - de(n) oude(n) (Gouverneur-)Generaal silerg lamenteert zeer dat hij dit nog op Zijn 75 jaar beleeven moet." 4)

In Holland schijnt er aanvankelijk opgewektheid genoeg bestaian te hebben om de handelsbetrekkingen met China ten spoedigste te hervatten. Met het begin van 1815 liepen tochl vier schepen naar Canton uit. Een er-

1) Bl. 111 van de $₫$ Bijdrage tot de kennis van den economischen toestand van Nederland in de jaren 1813-1816» (1916), door W. L. D. van den Brink: een goed proefschrift. In Hoek's «Herstel», staat op bl. 160 : f 375000 .

2) Verg. bl. 168 van mijn "Teruggave der Oost-Indische Koloniën» (1910).

3) Bij Van den Brink t. a. p. bl. 111.

1) In een der op bl. 827 vermeld bundels. 
ran was de Canton, kapt" Arends. Coldbery had hun ijver voor de wederaanknooping der betrekkingen zóó bemoedigend gevondien, dat hij het ontrangen bericht, over het doorgaan van dat schip in Juni 1815 van straat Sunda, den koning meldde. ') De vier schepen bereikten hun bestemming, deden er zaken en roeren ook over Batavia terug, toen den $10 \mathrm{k}$ septemler $1815 \mathrm{bij}$ Poeloe Condor de blilisem slueg in een clier scheper, De Żeploeg, kaptn Schindchutte of Schinderhutle, waardoor het vaartuig verbrandde. De gezagvoerdler maalite toen de reis met cle Canton, die dien $23^{\circ}$ Maart 1816 de Kaap bereikte; daar ontmoelte Van der Capellen op zajn vaart naar Batavia dit vaartuig. 2)

De besten onzer mannen in Nederland waren toenmaals van meening, dat zijn handel op China slechits goede toekomst kon hebben, wanneer die cloor een geldelijk krachtige, gemonopoliseerde maatschappij werd gevoerd. ${ }^{3}$ ) Die handel klecf in de eerste plaats beoogen het verkrigzen van thee. En al gold cie aanvoer jaarlijks slechts 'n 40.(16) kistjes " $)$, zulk cen alleen door monopolie te bewerkstelligen legrenzing hood het voordeel, dat de markt niet werd overstroomd, zijnde thee een artikel, waarvan het verliruik slechts een zeer beperkt karaliter droeg, zoodat ligt overvoer ontstond, en clus gevaar ran den prijs op een den geheelen handel dioodende wijze te zien dalen. De Amerikanen, die in den tijd, toen onze vaart niet vilig meer op zee was, de tusschenpersonen onzer theehandelaren werden, aldus ,nu eens roet in en kennis van onzen Thleehandel bekomen hebbende" zouden, zoo beeldde men zich in ${ }^{5}$ ), voortgaan ,om ons Vaderland en onze verkoopingem, ten koste onzer eigene scheepvaart, vam dit product te roorzien", wanreer wijzelven niet daartegen met vereende krachten opkwamen. Dit te eerder, omdat een expeditie tot inkoop van thee uit Europeesche havens naar Canton, een der meest kostlare was, welke gedaan kon worden; het gold hier geen Fagatel, welke men in den handel weleens wagen kon, maar tonsen schats, waarom men, werd betoogid i), ,deze handel zonder eene

1) Bij brief d.d. 5 December 1815 was het uit Londen aan Goldberg geschreven: zie Ternggave t. a. p., bl. 230.

3) Brief d d. 24 Februari 1816 van Van der Capellen in Teruggave $\mathrm{t}$ a. p. bl. 294.

3) Verg. Hoek t. a. p. bl. 309 ad noot 2; Muller t. a. p., dl. II, b. 173; mijn «Oost-Indië's Herstel» (1911), bl. 23, noot 2 .

1) Pouts t. a. p., bl. 17

5) Id. , bl. 9 .

-) Id. , bl. 15. 
vrij waarschijnlijke hoop op voordleel niet wagen kan of zal, on dat derhalve, indien de vooruitzigten slechts onzeker zijn, een voorzigtig Nederlandsch koopman geene expeditie derwaards zal ondernemen". Het schijnt wel een zeer gevaarlik koopmansartikel te zijn geweest; ook de later voor de Findicl-Maatschappij gekochite theeladingen ,hebben telkcns verlies gegeven", wordt getuigd. ${ }^{1}$ )

Onder dergelijke gedlachten waf onze Staten-Generaal het leven aan d.e wet van 23 Maart 1815, Ned. Etbl. $\mathrm{N}^{\circ}$. 30 , nog wel met de machilige stem van G. K. van Hogendorp, stichtend die levoorrechte $\mathrm{M}$ a a t $\mathrm{s} \mathrm{c}$ hi a $\mathrm{p} \mathrm{p}$ ij voor de $\mathrm{n} \mathrm{Ch}$ in eeschen the ehande 1: deze ,geliefde instelling des Konings", naar Goldberg's woorcen in een tot Commissarissen-Generaal in Indië gericht aanbevelend schrijven d.d. 14 Mei 1816. ${ }^{2}$ ) Op het statuair kapitaal van $f$ millioen werd echter slechts, niettegenstaande de krachtigste aanhevelingen, voor f 724.000 geteekend, w.o. door Z. M. voor 5 ton. ${ }^{3}$ ) zoodat de Maatschappij weldra cen cloodgeboren lind zou blijken. Het ware misschien niet recht te vatten, hoe onder die omstanclighedien aan de zaak nog een begin van uitvoering kon worden gegeren; doch de ondertoon van 's lands regeering was toenmaals doondrijven. Men meene ook niet, dat men roor de onregelmatigheid geen geopend cag heeft gehad, toen in Nederland de koning een schip ten laste der Maatschappij deed inhuren, de Hoop on Fortuin, a $m$ uit China thee te gaan halen. Ton minste, wanneer de gansche onderneming mislukt blijkt, en het uitgezonden vaatuig nog nieteens in het varlerland terug is, cloet men ter gelegenheid der rervangendie Theewet van 1817 in de $20 \mathrm{Ka}-$ mer de vraag over de op het kapitaal gestorte gelden: ,Of men daarmede dien hancel gedreren heeft, dan of dezelve ledig zijn blijven liggen?" - ees belangstelling, die reel had van naar den bekenden weg te vragen, zoomedie verwit in zich sloot - en deze andere viraag: "Hoe of de terenwoordige toestand van dit fonds is?", walrop ontwijkend ten antwoord werd gegeven, dat nog niets van den toestand viel te zeggen, zoolang het schip niet terug was, verder: "Dat voorts bi; gelegenheid van deze expeditie,

1) Muller t. a. p., di. II, bl. 335 .

$\left.{ }^{2}\right)$ Bl. 129, noot 1 van «Het Nederlandsch gezag over Java enz.» door M. L. van Deventer (1S91). Verg. E. de Waal's «NederlandschIndië in de Staten-Generaal", dl. I, bl. 15-16.

3) Zie bl. 109 Van den Brink t. a. p.; Memorieboek t. a. p. bl. 79. 
het een roorwerp van deliberatic is geweest of men dezelve met die gefourneerde gelden, roor rekening der deelhebbenden, of roor reliening vas het Rijk zoude doen, doch dat men heeft begrepen, dat de Maatschappij niet bestaande, immers niet op den roet, bij de wet bepaald, deze expeditie derhalve nict op de roorwaarden en bepalingen in dezelre roorkomende, zoude kunnen worden daargesteld, en clus de deelhebters in geval van verlies, met regt zouden kurnen staande houden, dat zij daarin nict rehoefden te deelen, door alle welke redenen men de overtuiging heeft bekomen, dat het rerkieslijk ware dieze expeclitie op zichzelve en roor lands rekening te bewerkstelligen." "1)

Maar wie ook aan de te dragen verantwoordelijkbeid: had moeten denken om de regeering van koning Willem I reeds aanstonds van diergelijlik ten ongeluk leidende maatregclen af to houden, nl. de departementschef ran Koloniën: van den zoo weinig karakter hebbenden Goldberg - ,dezen merkwaardigen dienalar van Willem I' roemt men hem andiers ! - viel cen dergelijke waarschuwing allerminst te verwachten. ${ }^{2}$ ) Zijn rapport d.d. \& Januari $1816 \mathrm{~N}^{\circ}$. 1 aan den vorst, waarin het gansche beloop der zaak worch in herinnering gebracht, leidcie er als het ware van zelf toe, om de vraag naar voren te brengen: , sire, $z$ oud $\mathrm{g}$ e d at we 1 do e $n$ ? Geen gchijn of schaiduw ran afkeuring echter van den weg dien men opging, speciaal ook niet, dat men in de sinds rereenigde Zuidelijke Nederlanden den invoer van thee tegen betaling der inkomende rechten maar toeliet naar het tarief der wet van 3 October 1816 , in weerwil ran het monopolie der Theewet van 1815.

Om de expeditie mogrelijk te maken, was meer fonds noodig dan toegestaan, waarom de departe-

1) Bl. 2-3 van het Rapport t.a. p. op de Theewet van 1817.

$\left.{ }^{2}\right)$ De aanhaling van $V a n$ den Brink t. a.p. bl. XI der Inleiding. Over Goldberg o.a. mijn Ternggaze t.a.p. bl. 113-114. Bijzonder merkwaardig inderdaad zijn gedachte om Indië te helpen aan valsche munt! Zie het bijna ongelooflijke op bl. 382-383 van mijn Muntepisodes in de Bijdragen van het op bl. 828 verneld Kon. Instituut, d]. 70 (1915). Kenschetsend is de brief van dezen baantjesjager aan Napoleon d.d. 13 Juli 1810: "Ayant cté le premier et le seul qui ait opiné ouverlement pour la rénion de mon pays à la Frances!! wordt de fooi gevraagd. "Puisse la Providence divine veiller sur les jours de $V$. M. et nous conserver longtems un souverain dont la sagesse et la volonté magnanime sont seules capables à dédommager les bons Hollandais des sacrifices qu'ils ont faits pour la cause commune. In d]. VI (1911) - hoofdstukken I-III - van Dr. Colenbrander's Gedenkstukken der Algemeene Geschiedenis van Nederland, bl. 3-4. 
mentschef aanrulling rerzocht. $\left.{ }^{1}\right)$ Goldberg sterlit dan den vorst in de expeditie naar China voor rekening van die Maatschappij als ,wi,ssel.jk gewild", „,om", luidt de lof over het doordrijven, ,daardoor-opentlijk te toonen, clat het Hoogstdeszclis onveranderde intentie is, dat dezelve Maatschappij tot stand wordic gebragl, ten einde den vervallen. Theehandel op eenigen zekicien voct hersteld en voor de algemeene belangen des Rijiks zoude wordien uitgebreid." De cieelneming Lleck wel tegengeloopen, niet echter omdat de strekking der Maatschappij. verkeerd geoordieeld moest wordon, matr, wit hoofdle van den oorlog, wellic het Vaderland, tijclens de uitvardiging van het Octroy, zoo onverwacht op nieuw werd aangedaan" en ,voornamelijk coor de tegonwerkingen "an het eigenbelang", mct wclke laatste reden de rapporteur wel op het oog zal gehad hebben het gemis arin ingenomenheid van relen, dat men nu wcer een soort van Oost-Indische Compagnie in het leven riep. ${ }^{2}$ ) Slcchts daardoor bleek men nog niet thet succes te hebben: ,als ran een zoowel cloordachte inrichting tot algemeen welzijn met rechen mogt wortlen verwacht". Zoo ging men in zee, zondier dat er zells hot statuair voorgeschitevery bestuur van de Maatschappij kon zijn; maar mondeling had de koning het hewind intusschen aan cien departcmentschef opgectragen! 3) Die on gunstig over de zaak oordeelden, heette har $v$ ij a n d ig on waren onvaderlanklslievend. Altid zou echiter de cigenwijze vorstelijke doordrijver het vadenland roor die mislukkingen doen bloeden.

III.

Terwijl Goldleng op de hij K. B. dicl. 15 Januari 1816 $\mathrm{N}^{\circ} .30$ gegeven machtigiris tot hot berachten van een schip roortwerlite, liwam er een verzock uit China ran de door hem als , cle commercichedienden te Canton" aangewezen personen; het antwoord erop zal wel eenigszins teleurstellend gewerkt hehlen. Zij waren voorloopig een eñ al ijver geweest. Aan den uit Europa ontvangen drang tot het toomen van helangstelling in de Theemaatschappji, was don hen geroig gegeren, niet

1) Het steeds den koning vlijend schrijven over de heerlijkheid van Hoogstdeszelfs vinding is vervat in een der op bl. 827 vermelde bundels, gelijk nu ook andere stukken, door mij zonder aanwijzing te noemen.

$\left.{ }^{2}\right) \mathrm{Zie}$ in bijzonderheden over de hierbedoelde «tegenwerkingen»: Memorieboek t. a.p., bl. 79-80; Tan den Brink t. a. p. bl. 110-111.

3) Goldberg schrijft dit in een van zijn nader te noemen brieven aan Bletterman c. s. 
alleen wijl Bletterman en Zeeman door Theysset en $\mathrm{C}^{\circ}$. hadden doen inteekenen voor zichzelien, maar ook, naar deze firma eerst berichtte, voor 1 en vervolgens nog voor 2 Chineesche kooplieden, daartoe door hen overgehatald, elk zelfs roor 10 aandeelen à f 1000 . De beide factorijheeren en Rahihel verzochten nu echter mede d.d. 15 October 1815 aan het $\Lambda$ msterclamsche huis om voor hun belangen te willen waken, opdat uit aanmerking ran hutn reeljarigen, doch ongelukkigen dienst geen nieuwelingen of vreemden foren hien werden geplaatst. Bij brief did. 27 Maart 1816 brachten Theysset en $\mathrm{C}^{\circ}$. dientengevolge onder Goldberg's aandacht, gelijk het in diens verbaal d.cl. 28 d.a.r. No. 79 luidt, hum rerzoek: ,om bij de invoering der nieuwe Directie op Canton, naar aanleiding van hunne langdurige diensten bij 't Gouvernement, alle mogelijke protectie". Bij brief d.d. 1 April $1816 \mathrm{~N}^{\circ}$. 2 antwoordcle de departementschef aan de firma: "dat het Zijner Majesteits intentie schïnt te zijn, om de Nederlandsche factorii te Canton te stellen onder de onmiddellijle directic van het Bewind over de Chinesche Maatschappij", juist clus wat eigenlijk werd gevreesd; dat bevind luidt ook als een roortzetting van den tijd der "Bewindhlebbers" van de O. I. C. ! Hun toeliomst zou alzoo Goldlerg aan het door $Z$. M. te benoemen bewind overlaten: ,om $1 \mathrm{jj}$ een eventueele organisatie clier factorij" zoodanige bepalingen te maken, als roor de belangen der $\mathrm{M}$ ij. wenschelijk mocht blijken; tot zoolang kon men, gecne verandering in de ambtenaren te Canton" maken en wille men alzoo ,de-. zelve in hunne posten laten continueeren provisioneel op den vorigen voet". De regeling hunner positie moest dus, besloot het antwoord, ,zeer reel van de ambtenaren zelve afhangen", opdat ",zij door rigilantie en goede behandeling der Eerste Expeditie zich het vertrouwen van het Bewind der Maatschappij trachten te verwerven, en daardloor deszelfs gunstige clispositie te meriteren".

Met het besluit tot uitzending van de Hoop en Fortuin was er eerst aanleiding roor Goldberg om aan de factorijheeren rechtstreeks te schrijven, hetwelk geschiedde in twee depêches, die gericht werden de eene „Aan het opperhoofd en verdere leden van den Commercie Raad der Nederlandsche factorij te Canton in Chinja", de andere "Aan de heeren J. H. Bletterman en Berns. Zeeman, ledien enz.". Een ervan harudielde over de theemarkt te Canton, waaromtrent diezen hadden ingelicht, dat onderscheidene scheepsladingen konden verkregon worden. In verband hiermede de depêche d. d. 15 October 1816 No. 21. Door den koning 
was besloten tot het zenden van één schip; maar nu rees het $Z$. $M$. in gedachten om nog één of twee schepen var de naar Batavia vertrekkende militaire Twee. de expeditie bij aankomst aldaar te doen charteren voor een reis naar China, indien dit dan geraden bleef. ${ }^{1}$ ) Hierover moesten zij op ontvangst der depêche dadielijk de regeering te Batavia inlichten. De andere depêche droeg de dagteekening' $\operatorname{ran} 26$ November $1817 \mathrm{~N}^{\circ}$. 1; zij trad in breede uiteenzetting over de Maatschappij en over het gecharterde schip, waaruit cok kleek de onzekere staat van het handelslichaam. IIun betrelikingen werden gerekend in te gaan met 1 Januari 1817, doch over hun financieele positie werd nor niets hoegenaamd b e paald. ,Deze provisicneele voortduring van zaken op den oudlen voet" moest hen echter niet ontmoedigen, spoorde de depêche aan, of hun ijver ter behartigting van de belangen der $M^{\mathrm{ij}}$. doen verflauwen; ,maar veeleer aansporen tot verdubbelen in getrouwheid en activiteit om eene naamwaardige verbetering te verdienen." Compleet de Goldhergsche manier. Terens besloot de idepartementschef om mede te werken tot het uitkeeren van een premie aan hen. Alclus de toekomstmuziek voor deze menschen na hun verheugenis over het Herstel!

Irgevolge de behoorlijk ontvangen depêche van 15 October 1816 schreef de factorii, zooals ik kortheidshalve het kantoor van Bletterman c.s. zal noemen, maar zij had geenerlei officieele organisatie, d.cl. 10 Februari 1818 naar Batavia. Het in December 1816 uitgezeilde schip, dat later vertrok dan was mediegedeeld, maakte bovendien een buitengewoon ongelukkige reis; enkel om Batavia te bereiken zou een jaar noodig blijken: 31 December 1817-5 December 1817! 2) Intusschen dreigdie de goede tijd te Canton voor het verzenden van thee

1) De lezer worde hier niet door van Goldberg's aanvankelijk genoemde «Eerste Expeditie» en nu «Tweede Expeditie» in verwarring gebracht. Met die Ferste expeditie wordt hier bedoeld de eerste uitzending voor de Theemaatschappij; doch er was in 1816 uitgegaan de Eersle militaire expedilie ter overneming onzer koloniën, waarop in 1817 een tweede volgen zou; deze laatste meent Goldherg met de Trueede expeditie. Zie de bijzonderheden over de z.g. Tzueede expeditie mij̣n verhandeling in de Bijdragen van het op bl. 828 vermeld Kon. Instituut, dl. 67 (1912), bl. 628 v.v.

2) Ik heb het verhaal over de uitrusting van het schip met al hetgeen er bijkwam - anders lang niet onaardig - kortheidshalve onvermeld gelaten; evenzoo Goldberg's brieven zeer aanzienlijk verkort. Over de wanhopend rampspoedige reis van de Hoop en Fortuin deelde $\mathrm{ik}$ reeds enkele bijzonderheden mede, in de verhandeling der vorige noot, bl. 656-660. Het schip, ofschoon voor China bestemd, 
voorbij te gaan. De factorij verzocht daarom machliging aan de Indische regeering om indien de Hoop en Fortuin nog niet in Juli of Augustus Canton had bereikt, vaartuigen aldaar te mogen huren ,ten einde dezelve vór de voorjaarsverkooping van 1819 in $\mathrm{Ne}$ derland aangeland kumners zijn'. ') Maar reeds hadden ongunstige berichten over de toetromst der Theemaatschappij Bataria bereikt, ofschoon nog nicts officieels was vernomen, toen het Amerikaansche schip Asia, dank zijn vertrek ran Batavia d.d. 9 April 1818 naar Canton, aan de regecring gelegenheid gaf $\mathrm{cm}$ te antwoorden, gelik bij schinijven d.d. 6 t. v. No. 3 geschieddle. ${ }^{2}$ ), ,Ten aanzien van de voortzetting des handels op het rijk man China geene bevelen van het Gouvernement uit Nederland"' ontrangen hebbende, kon op het voorstel niet worden ingegaan, ,terwil dat particuliere tijdingen de intrekling der Compagnie voorstelden als eene zaak, welke in de najaarsvergadering der Staten-Generaal van 1817 derzelver beslarg stond te verkrijgen"; het was ,ondertusschen zekcr, en blijkt uit de couranten, dat er eene wet op de thechandel in het vaderland is rastgesteld, doch die wet zelve wordt in de dagbladen, voor zoo verre wij die ontvangen hebben, niet genoemcl." "Ondiertusschen", zoo besloot dit schrijren, ,zullen wij het een punt ran nadere overweging maken, of wij hier nog eenige uitrusting zullen bevelen naar aanleiding van cle voorstellen door U.Ed. gedaan." Commissarissen-Generaal vervolgden deze depêche met een, vastgesteld in hun vergadering d.d. 22 Mei $181 \mathrm{~s}$ $N^{\circ}$. 35. De conceptwet op de Thee, waarmede het monopolic, dat de Theemaatschappij had gekregen, zou worden ,vernietigd", was, werd gememoreerd, in cie Bataviasche Courant verschenen ${ }^{3}$ ); uit dien hoof-

(het verzeilde intusschen naar Noorwegen!!) maakte namelijk ook deel uit van de z.g. Tiveede militaire expeditic; maar men bleef het beschouwen alsof het er niet toe behoorde. Vandaar dat ik, in onbekendheid hiermede, gewaagde van 9 koopvaardijschepen (op bl. 635 mijner verhandeling), welke die expeditie telden, terwijl officieel slechts 8 worden genoemd. Ook over dit incident der toevoeging aan het militaire transport, heb ik kortheidshalve hier verder gezwegen.

1) De aanhaling, getrokken uit het besluit der C. C. G. G. d.d. 15) Maart 1818, No. 11 .

2) Besluit d.d. 24 Maart $1818 \mathrm{~N}^{\circ}$. 12, overeenkomstig het advies van den Raad van Financiën d.d. 18 t. v. No. 16. Het vertrek van de Asia in de Bataviasche Ct. d.d. 11 April 1818 №. 15 .

$\left.{ }^{3}\right)$ Ik heb er te vergeefs naar gezocht. Wel is in die courant, $\mathrm{nl}$. van 20 Juni $1818 \mathrm{~N}^{\circ}$. 25 , op bl. 2 de tot stand gebrachte wet van 24 December 1817 opgenomen. Het ontwerp las ik echter bij de op 
de zeiden C.C.G.G. zich te harasten met kennis te geven ran hun voornemen:, om in dezen stand van zaken voor de Chineesche Theecompagnie geene uitrustingen te doen, maar af te wagten wat het gerolg zijn zal, dat aan de voorgedragen wet zal worden gegeven".

Het hier bedoelde ontwerp was cl.d. 22 October 1817 bij de Staten-Generaal ingediend. De toelichting herinnerde aan , cle misludite procf met de exclusive Maatschappij ran 23 Maart 1815". ') Zonder genade werd 's konings geliefde instelling als in strijd met , het algemeen belang van den handel in verband met het intrest der publieke schatkist" ten ondersten boven geworpien en de kermis der vrijheidd opnieuw - blijkens ondervolgende bewoordingen ingeluid - ook in verband met hetgeen zoo weinige jaren later zou gebeuren, lezenswaard:

Maar ook het belang der publieke Schatkist schijnt door het daarstellen of handhaven van een monopolie, aanmerkelijk te zullen worden benadeeld, daar het zeker is, dat hoe meer de vrije handel en het vertier worden uitgebreid en aangewakkerd, des te meerder inkomende regten worden geheven, en daar en boven het eene uitgemaakte waarheid is, dat de bloei van den eenen handeltak met die van alle de anderen in verband staat, zoodat door de uitbreiding van den één tevens aan de vermeerdering der anderen wordt bijgedragen, en alzoo de algemeene industrie en welvaart in verband met het publiek intrest van den Staat worden aangewakkerd, bevorderd, en hoe langer hoe meer op vaste zuilen gevestigd.

En, Edel Mogende Heeren! er moge dan omtrent de toepassing dezer waarheden op het stuk van den Theehandel, bevorens eenige twijfel bij sommigen hebben bestaan, de ondervinding van den laatsten tijd, de meerdere ontwikkeling van de vrije beginselen van Koophandel en Zeevaart, die sedert de bevestiging der dierbare onafhankelijkheid van Ons gelukkig Vaderland, met zulke vaste schreden voorwaarts gaat, en de algemeene stem van de voornaamste en meest geïnteresseerde koopsteden, hebben als nu het pleit voldongen, en de zaak ten voordeele van den vrijen handel beslist.

Maar hoe nu met de aandeelhourlers, die hun geld hardden gestort en hetwelk, tegen de wet der geoctrooieerde Maatschappij in, willekeurig gebruikt was gewordien, daar ,noch de provisionele noch de definitivie bepalingen, omtrent het roorloopig of duurzaam beheer der Maatschappij, die bi: art. 14 en 17 der wet gemaakt zijn, derzelver effect gehad hebben", erkende de Toelichting. Men kikte er niet van, dat de regeering er eigenlijk roor verantwoordelijk moest gesteld worden. $\mathrm{Zij}$ verklaarde het nu

bl. 828 sub 4 vermelde Toelichting op de wet; in art. 1 ervan kwam het «vernietigd" voor; de redactie werd echter veranderd op aanmerking der Vertegenwoordiging: Rapport t. a. p., bl. 2.

1) Zie, ook voor wat verder volgt, bl. $2-4$ der Toelichting t. a.p. 


\section{2}

,,door de regtvaardigheid te worden voorgeschreven, dat wan de genen die hunne penningen verstrekt hebben, derzelver verstrekte kapitalen behooren te worden terug rregeven, en zij roor het gemis derzelve, met den redelijken intrest ran 5 per cent, zoo als die bepaling bij artikel 2 der nieuwe wet voorkomt, behooren schadeloos gesteld te worden', uit 's Rijks schatkist! Art. 2 van het Ontwerp stelde, clat dit dan ook z o o ll r a mog e$1 \mathrm{ij}$ k zou geschiedien; maar zelfs dit werd niet voldoende in de Vertegenwoordiging geacht, nl. ,teneden de waardigheid van het Gourernement", in zoover men het in $\mathrm{d}$ a $\mathrm{d}$ e 1 ij $\mathrm{k}$ veranderde ! ${ }^{1}$ )

Zoo gal dan de Theewet van 24 December 1817(Ned. s.thl. $\mathrm{N}^{\circ}$. 36) an ieder c.e vriheid om in het product te handielen terug. Als publiek lichaam sncefde daar. mede het, Institunt der Paklinis-meesteren te Amsterdam, om echter met 1 Januari 1818 in zijn plaats te doen treden een particulier ,"Thee-etahlissement". ${ }^{2}$ ) Marar zoo groed als geen ischepen rertconden vooralsnog de Nederlandsche vlag mecr in China. De Chincesche jonken en met name Ametiliaansche schepen voerden de producten van het Hemelsche rik te Bataria aan.

Op de expeditie der Hoop en Fortuin kom ik in mijn vermeld Nijhoffwerk terug. De kosten ervan werden, tengevolge van deze tweede Theewet, ,thans voor re'sening van het Gouvernement" overgenomen, berichtte minister Falck, opvolger van directeur-generaal Goldherg. ${ }^{3}$ ) Orerigens bracht, gelijk opgemerkt, de wedergegeven vrijheid gees heil meer aan: , met onze wereidmarkit voor Chincesche thee was het gedaan, voor iroed", heet het einde der geschiedenis van het met 1824 afgesloten tijclvak. 1) In overeenstemming hiermedle luiddde het troosteloos in de nader te ncemen resolutie der Indische regeering d.d. 28 Decemter $1824 \mathrm{~N}^{\circ} .4$ over de vooruitzichten tot het aanmoedigen en vestigen van handelsbetrekkingen tusschen Nederland en China, dat: ,de kwijnende staat des handels tusschen deze Rijken en het eiland Java geene waarschijnlijkheid oplerert, clat tot het daarstellen van gem. handelshetrekkingen eene gunstige gelegenheid zich spoedig zal aanlieden".

1) Zie ook Rappont t. a. p. bl. 3.

2) Memorieboek t. a. p. bl. VI-VII der Inleiding.

$\left.{ }^{3}\right)$ Depêche d.d. 14 Juni 1818 op bl. 250 van het op bl. 835 noot 2 vermelde werk van $V$ an Deventer.

') Muller t. a. p. dl. II, bl. 176. 


\section{IV.}

De heeren der Compagniesfactorij te Canton hebben het in zekeren zin wellicht getroffen, dat zij niet met een bewind, zooals het immers heette, der nu ycsneefde Theemaatschappij te cloen kregen. Bij de behandeling der Theewet lan 1817 heck nen in de 20 hamer welwillend genoeg over hen te denken, daar werd opgemerkt : 1)

Men heeft voorts bij deze gelegenheid, hoewcl zulks geen bestanddeel der concept-wet uitmaakt, in bedenking gegeven of de instandhouding van de bestaande Nederlandsche factorij te Kanton niet zeer nuttig zuude zijn, vooral voor de inkoopen tot geringe prijzen in de zoogenaamde stille tijden, en men heeft geene reden gezien, waarom de factorij ook niet den vrijen handel zoude kunnen bedienen. De traktementen en het onderhoud der gebouwen zouden wel iets aan het land kosten, clan de Nederlandsche schepen, die zich van de factorij bedienen, zouden eene geringe belasting te Kanton kunnen opbrengen, hetwelk in mindering van de kosten van hot Rijk zoude strekken.

Waarop de regeering artwoordde, nict, dat een clergelijk officieel hanclelskantoor weinig bestaanbaas scheen met het besluit der regeering um niet meer te handelen, maar :

Wat dit onderwerp betreft, zoo heeft men de nuttigheid van het behoud der factorij buiten allen twijfel gesteld; en vermeent de stellige verzekering te kunnen geven, dat het $Z$. M. intentie is dezelve te behouden, en men heeft tevens begrepen, dat daar de knsten voor het instandhouden derzelve niet zwaar zijn, de voorgestelde heffing van eenige regten op de Nederlandsche schepen konde achterwege gelaten worden.

Met de sinds verrichte werkzavamheden der factoril, ben ik niet bekend, evenmin met hetgeen toch hare organisatie was, zoo er een geweest is. Dat men haar voortbestaan op prijs stelde, bewijst nog het gebeurde in 1822 , toen de gebouwen afbrandden en ze herbouwd. werden ${ }^{2}$ ), ja maar op kosten der Inclische kas! Ln in dit licht verschijnt ook de breede in de StatenrGeneraal verkondigde opvatting om de geringe kosten der factorij niet te tellen: alles kwam ten laste van Indië, ook de schulden uit den ouden tija!! Dit worcit ons nog uitdrukkelijk herinnerd, toen slechts kort daarna de instelling, met behoud der heeren Bletterman en Zeeman ails werd omgezet in een consulaat: een voor de heeren

1) Rapport t. a. p. bl. 12-13.

2) Muller t. a. p. dl. II bl. 176 . 
belangrijle organisatie. De een werd chef, de ander adjunct. Gelijk geheel het verleden van het handielskiantoor voor den geschiedschrijver tot dusver in een waas van onzeherheid gehuld is geweest, zoo merkt men dit evenzeer hij hlaar geschiedenis van dre 190 eeuw, waardoor ook de publicatiën erover eenheid van voorstelling missen.

Er zal, naar ik denk, wel over het beginsel van het consulsschap uit een staatkundig oogpunt van gedachten zijn "gewisseld. Wij wilden geen consuls van andere mogendheden in onzen Indischen archipel ontvangen en daarom ook niet Nederlandische rertegenwoordigers in vreemde koloniën plaatsen, zoodat wederkeerigheid geen aanspraak op recht kon schenken; een belangrijk rapport hierorer werd door Van der Capellen als lid der Commissie-Generaal medie onderteekend. Elout was er dus ook tegen; het opperbestuur, Goldberg, Falck mede. Aan Engeland, aan Frankrijk haciden wij het benoemen van consuls ir onze bezittingen geweigerd, nog uitdrukkelijk bij de onderhandelingen voor het I-ondensahe tractaat van 1824.1$)$ En toch ongeveer te gelijkertijd promoveerden wij Bletterman en Zecman, en bij het overlijden rån dezen, Van Caneghem, tet consuls te Caunton. Misschien hebben wij ons gerleid, dat, zooals de toestanden in het Chireesche rijk waren, wel geen oorzaak tot wederkeerigheid te rerwichten stond of dat deze slechts had te keteekenen plaatsing van consuls in Nederland, in ieder geval er zijn geen reclames gekomen; misschien ook achtte men deze verandering voldoende gemaskeerd, doordien de factorij als gouvernements instelling toch behoudien bleef en derhalve in zoover de werkkring der constuls niet veranderde. Het hliervoren vermelce antwoord van de regeering bij de behandeling der Theewet is dus met zulk een regeling in overeenstemming. ${ }^{2}$ ) Men clenke er aan, opdat niet onwillekeurig worde vermeend, dat toen men van factorij bleef spreken, ook na 1824, hiermede niet bedoeld werd een kantoor der Nederlandsche Handielmaatschappi.j, heb. bende deze integendeel te Canton nooit een vast agentschap gehad. ${ }^{3}$ ) Het scheelde trouwens zoo heelveel niet, dat het publiek ons consulaat te Canton met de Handelmaatschappij vereenzelvigde; want de gebouwen der

1) Zie mijn "Oost-Indië's inwendig bestuur» (1918), de $§ i$ op bl. 261 over dit belangrijke onderwerp in zijn geheel. Zie mede de hiervóór op bl. 830 noot 4 vermelde Bijdragen van Van den Berg: bl. 365 v.v.

2) Zie bl. 843 .

3) Muller t. a. p. dl. II, bl. 330 , 
gouvernementsfactorij wces men aan als ,Nederlandsche consulaatspakhluizen", diezelfcle factorij ais de ,Maatschappij", consul Bletterman als het plaatsclifik hoofd der "Maattschappiy". ') 't Was ook wel wat oneigenli,k de organisatie dezer handelspakhuizen met de consuls als hun hoofden, die ze moesten verhuren aan andere kooplieden, gelijk de Handclmaalschapp.j en warvan deze het meest gebruik maklite.

Ziehier nu de stichting ran het consulaat, althins roor zoover ik slechts van één stuk kennis nam.

Het Kon. besl. d.dl. 21 ^ugustus 18:2 N N. 81 had over de regeling cler inkomsten ran onzen consul cn zijn adjunct te Canton bepards, dat deze roor het grootste dreel uit vaste jaarwedder zouden hestaan. De Indische resolutie van $15 \mathrm{Juli} 1823 \mathrm{~N}^{\circ}$. 2 stelde clicrengevolge het maandielijksch traktement roor dien consul op f 2200 en voor den adijunct op f 1320. Bletterman liwam natar Batavia en besprak er de zaken van het consulaat. Hieruit ontstond hiet cerste $\mathrm{R}$ e g I e m e n t voor het Ne de rlandsch Consula t te Canton in China, dat echiter slechts provisioneel werd rastgesteld hij de resolutie in Radie dl.d. 28 December 1.824 No. 4. Behalve dit reglement hield de resolutie talrijke andere mededreelingen in ${ }^{2}$ ), zoodlat hot ean groot stuk is geworden. Volgens art. $\&$ van het Reglement was het aan Consul en $A \mathrm{dju}$ n c t-C on sul geoorloofd, ,particulieren handel te drjjen, en als agenten kommissiën aan te nemen." ; volgens art. 7 konden zijlaan de scheepsoverheid, welke ter bestiering hunner ondernemingen zich tot het consulaat zullen wenden" voor commissiegelden in rekening brengen $2 \frac{1}{2} \%$ op de aangebrachte en $3 \%$ op de retourladingen. Van cle commissiegelden werd den consul $3 / 4$, den adjunct $1 / 4$ toegewezen. Evenals de genoemde schuld der factorij ${ }^{3}$ ), clrulkten de traktementen der heeren, lezen wij er, ,en alle de verdere uitgaven voor het Nederlandsch consulaat in China, als een aanmerkelijk bezwaar voor de Indjsche kas", ofschoon , dloor hiunnen aard als aan dezelve geheel vreemd moet worden beschouwd"', luidkle de klacht in de overwegingen. De betrekkelijk groote bezoldigingen werden, blijkens de overwegingen, verdedigd wegens: ,de langdurige dienst van den Heer Bletterman als opper-

1) Muller t. a.p. dl. II, bl. 331-332, 333, 335.

2) Op het Rijksarchief in den bundel der Schneitherverzameling, jaarverslag 1915, bl. 355 No. 134. Hiervóór op bl. 842 deze resolutie reeds aangehaald.

3) Verg. bl. 832 ; echter nu berekend op f 280880. 
hoofd van de voormalige Nederlandsche factorij, gevoegd bij het gemis der zooveel ruimere inkomsten, welke de ledicn dezer Factorij voorheen, bij eenen meer levendigen handiel en vaart op $C$ hi n a genoten en waarvan gem. amltenaar, en zijn nu wijlen ambtgenoot $\angle$ e em a n sedert den jare 1794, en dus bijna gedurende den ganschen tijd van hunnen dienst, verstoken zijn geweest, terwijl daardoor alle derzelver billijke rooruitzigten op eene verbetering van hun lot, verijdeld zijn geworden allezins consideratiën verdienen . en aan gem. Heer Bletterman eene billike aanspraak op eenige tegemoetkoming van de zijde van het Indische Gouvernement geven". Heer Zeeman overlijdende, was hiij door $\mathrm{V}$ a n $\mathrm{C}$ a $\mathrm{n}$ e $\mathrm{g}$ he $\mathrm{m}$ als adjunct opzerolgd. 1) Art. 1 1r. a der resolutie van 1824 steldie vast, dat deze in 1823 verorderde inkomsten, ,voorloopig op denzelfdien voet zullen blijven bestaan". "2) Hoe lang dit gedduurd heeft, weet ik weer niet; van weinige jaren later lees ik over de ,matige bezoldiging" van, \$ $\$ 1200$ per jaar", dus per ja a 1 , doch de consuls "mochten zaken doen voor eigen rekening". ${ }^{3}$ ) Eindeli k, "wanneer wij in het jaar 1840 zijn gekomen, heet het ,gedaan mot het laatste overblijfsel onzer Oost-Indische Compagnie in China, met de aloude 'Hollandsche factorij' te Canton'. ${ }^{1}$ ) Iien handelsvestiging van een Nederlandsche overheid zou er niet meer herrijzen.

's-Grarpenhaige, December 1918.

P. H. van der $\mathrm{Kem}$.

1) Over Van Caneghem, een Belg, zie Muller t. a.p. dl. II, bl. 327 en 331 . Wanneer Zeeman overleed en of hij nog als adjunctconsul fungeerde, gelijk ik veronderstel, weet ik eigenlijk niet.

2) Het zou echter bij overlijden van Bletterman kunnen verminderd worden voor den consul, stond er. Het traktement van den adjunct schijnt men laag genoeg geacht te hebben.

3) Mvller t. a.p., bl. II, h. 330.

4) Id. bl. 342 , 